\title{
Cruel and Unusual Punishment and Sodomy Statutes: The Breakdown of the Solem $v$ Helm Test
}

\author{
J. Drew Page $\dagger$
}

In Bowers $v$ Hardwick, ${ }^{1}$ the Supreme Court upheld Georgia's sodomy statute ${ }^{2}$ as applied to consenting adults of the same sex. Writing for the Court, Justice White held that there is no constitutional right to engage in sodomy. ${ }^{3}$ In a brief concurring opinion, Justice Powell agreed that "there is no fundamental right-i.e., no substantive right under the Due Process Clause" to engage in consensual sodomy, ${ }^{4}$ but suggested that Hardwick might be protected from prosecution by the Eighth Amendment's prohibition against cruel and unusual punishment. "The Georgia statute . . . authorizes a court to imprison a person for up to 20 years for a single private, consensual act of sodomy. In my view, a prison sentence for such conduct-certainly a sentence of long duration-would create a serious Eighth Amendment issue."s

This comment discusses whether a prison sentence for a term of years for violation of a sodomy statute could constitute cruel and unusual punishment. In Hardwick, the Court limited its holding to homosexual sodomy. ${ }^{6}$ This comment is similarly limited to the analysis of sodomy statutes as applied to consenting homosex-

$\dagger$ B.A. 1986, Brigham Young University; J.D. Candidate 1989, The University of Chicago.

1478 US 186 (1986).

2 Ga Code Ann § 16-6-2 (Michie 1988) provides:

(a) A person commits the offense of sodomy when he performs or submits to any sexual act involving the sex organs of one person and the mouth or anus of another....

(b) A person convicted of the offense of sodomy shall be punished by imprisonment for not less than one nor more than 20 years. ...

3 "It is obvious to us that neither of these formulations [of fundamental liberties either implicit in the concept of ordered liberty or deeply rooted in this Nation's history] would extend a fundamental right to homosexuals to engage in acts of consensual sodomy. Proscriptions against that conduct have ancient roots." Hardwick, 478 US at 192.

4 Id at 197.

5 Id. Justice Powell did not press the Eighth Amendment issue, since Hardwick had not been tried, convicted, or sentenced. Further, Hardwick had not raised the issue in the lower courts. Id at 197-98.

- Id at $188 \mathrm{n} 2$. The language of the Georgia statute, however, was not limited to homosexual conduct. See note 2 . 
ual adults. ${ }^{7}$

The Eighth Amendment, which applies to the states through the Due Process Clause of the Fourteenth Amendment, ${ }^{8}$ prohibits the states from imposing "cruel and unusual punishments." In his Hardwick concurrence, Justice Powell seems to argue that Hardwick's potential sentence would be disproportionate to his crime. ${ }^{10}$ However, historical sources do not clearly indicate that the Eighth Amendment was intended to include such proportionality requirements. It appears that the language of the amendment was borrowed from the English Bill of Rights of 1689.11 It is not clear, however, how the English intended that language to be interpreted. Some legal historians believe that the provision was a reaction to the "Bloody Assizes" of 1685, which involved inhumane and barbarous punishments. ${ }^{12}$ Under this interpretation, the provision encompasses only punishments that are physically painful. Other historians believe that, while the provision was meant to proscribe such punishments, it was also meant to proscribe any punishment found to be too harsh in relation to the crime, following the tradition of the Magna Charta of $1215 .^{13}$

Even if the meaning of the English provision were clear, the interpretational difficulties would not end since there is some doubt as to whether the Framers meant to adopt the English meaning along with the English words. Indeed, one commentator

7 Cases that find a due process right to privacy, such as Roe $v$ Wade, 410 US 113 (1973) (recognizing a woman's right to have an abortion) and Griswold $v$ Connecticut, 381 US 479 (1965) (recognizing a married couple's right to use contraceptives) protect certain privacy rights of consenting heterosexual adults that the Hardwick Court held did not apply to homosexuals. Hardwick, 478 US at 190 . These cases may indicate that laws criminalizing heterosexual sodomy are unconstitutional.

- Robinson v California, 370 US 660 (1962).

- The Eighth Amendment declares: "Excessive bail shall not be required, nor excessive fines imposed, nor cruel and unusual punishments inflicted." US Const, Amend VIII.

10 See text at notes 22-24.

${ }^{21}$ The English Bill of Rights of 1689 states: "excessive bail ought not to be required nor excessive fines imposed nor cruel and unusual punishments inflicted." Stephen B. Baxter, Basic Documents of English History 161 (Houghton Mifflin, 1968).

12 See, for example, Joseph Story, 2 Commentaries On The Constitution $\$ 1903$ at 650 (Little, Brown, 5th ed 1891); Note, What is Cruel and Unusual Punishment, 24 Harv L Rev 54 (1910); Note, The Cruel and Unusual Punishment Clause and the Substantive Criminal Law, 79 Harv L Rev 635 (1966).

${ }^{13}$ The Magna Charta states that "[a] free man shall be [fined] for a small fault only according to the measure thereof, and for a great crime according to its magnitude." Baxter, Basic Documents at 26 (cited in note 11). Two historians who believe the English bill includes disproportionality are Anthony Granucci, "Nor Cruel and Unusual Punishments Inficted:" The Original Meaning, 57 Cal L Rev 839, 860 (1969), and Richard L. Perry, ed, Sources of Our Liberties 236 (Am Bar Found, 1959). 
has argued that the Framers misunderstood the English bill and thus attached a different meaning to the provision than did the English. ${ }^{14}$ The debates of the Constitutional Convention and the First Congress do not discuss the concept of proportionality in any way. Although these debates clearly show that the Framers meant to proscribe inhumane and barbaric physical punishments, ${ }^{15}$ they provide little guidance on whether the Framers intended to prohibit disproportionate punishments.

Nevertheless, the debate over the Framers' intent continues to be waged in recent Supreme Court cases. Justice Powell has argued that the Framers of the Eighth Amendment adopted not only the language of the English Bill of Rights, but also the English principle of proportionality. ${ }^{16}$ Chief Justice Burger has disagreed, claiming that "the more common view seems to be that the Framers viewed the Cruel and Unusual Punishments Clause as prohibiting the kind of torture meted out during the reign of the Stuarts."17 These varying characterizations of the Framers' intent highlight the difficulty of relying on the history of the Eighth Amendment to determine its scope and suggest that, ultimately, any such reliance is misplaced.

In the absence of solid historical evidence of the Framers' intent, this comment assesses Supreme Court interpretation of the amendment. Section I analyzes the only branch of Eighth Amendment jurisprudence applicable to homosexual sodomy-the proportionality test. Section II applies the Supreme Court's current proportionality jurisprudence to existing sodomy statutes and concludes that these statutes do not impose cruel and unusual punishment when applied to homosexual sodomy. Section III then

24 Anthony Granucci has suggested that the English Bill of Rights was intended to outlaw punishments "which were [first] unauthorized by statute and outside the jurisdiction of the sentencing court, and second, a reiteration of the English policy against disproportionate penalties." Granucci, 57 Cal L Rev at 860 (cited in note 13). However, Granucci believes that the American Framers misinterpreted the English meaning of cruel and unusual punishments, thinking that their own Eighth Amendment would outlaw only barbarous methods of punishment. Id at 860-865.

1s For example, at the Virginia ratifying convention Patrick Henry expressed fear that without a cruel and unusual punishments clause, Congress "may introduce the practice ... of torturing, to extort a confession of the crime." Jonathan Elliot, 3 Debates on the Federal Constitution 447-448 (1876). In fact, during debate on the adoption of the Bill of Rights in the first Congress, Representative Livermore opposed the Eighth Amendment because "villains often deserve whipping and perhaps having their ears cut off." 1 Annals of Cong 754 (1789).

16 Solem v Helm, 463 US 277, 285-286 (1983); Rummel v Estelle, 445 US 263, 287-288 (1980) (Powell dissenting).

${ }_{17}$ Helm, 463 US at 312 (Burger dissenting). 
defends the utility of dormant sodomy laws against the criticism that as a result of their desuetude they are cruel and unusual. Finally, section IV discusses state and federal sodomy cases that have considered the cruel and unusual punishment argument. These cases uniformly reject any Eighth Amendment challenge to sodomy statutes.

\section{Current Proportionality Jurisprudence}

Whatever the original intention of the Framers, the Supreme Court currently recognizes four situations in which a punishment may be struck down as cruel and unusual: 1) when the death penalty is imposed,18 2) when an inhumane or barbarous type of punishment is imposed; ${ }^{19} 3$ ) when the punishment is based solely on

28 In 1972 the Supreme Court first held, in Furman v Georgia, 408 US 238 (1972), that imposition of the death penalty for rape and murder in the cases before it constituted cruel and unusual punishment. Although the per curiam opinion did not explain the basis for its conclusion, the lengthy concurring opinions emphasized, not the inherent cruelty of the death penalty, but the fact that it was often administered in a discriminatory way. Id beginning at 240. Four years after Furman, in Gregg $v$ Georgia, 428 US 153, 169 (1976), the Court clarified its position on the death penalty holding that it "does not invariably violate the Constitution." In 1977 and 1982 the Court applied a proportionality analysis to death penalty cases, striking down death as a punishment for rape, Coker $v$ Georgia, 433 US 584 (1977), and accomplice felony murder, Enmund $v$ Florida, 458 US 782 (1982). The Supreme Court held that the punishment of death was excessive because it was disproportionate to the crimes involved. The holdings in Coker and Enmund relied on a test of proportionality originally outlined in Gregg. "Under Gregg, a punishment is 'excessive' and unconstitutional if it (l) makes no measurable contribution to acceptable goals of punishment and hence is nothing more than the purposeless and needless imposition of pain and suffering; or (2) is grossly out of proportion to the severity of the crime." Coker, 433 US at 592.

The applicability of the Gregg test to other punishments, including imprisonment, is doubtful because of the Court's continuing emphasis on the unique nature of the death penalty. "We have the abiding conviction that the death penalty, which is unique in its severity and irrevocability', . . . is an excessive penalty for the rapist who, as such, does not take human life." Id at 598. In fact, the Gregg proportionality test has not been applied to any punishment other than the death penalty.

19 The Supreme Court has invalidated three statutes during the last one hundred years that the Court felt allowed inhumane or barbarous punishments. All three cases involved forms of punishment that went beyond imprisonment. In Weems $v$ United States, 217 US 349 (1910) the Court held a Philippine statute, imposing cadena temporal for falsifying a public document, unconstitutional as cruel and unusual punishment. Cadena temporal was a very harsh penalty involving chains on the ankles and wrists, hard labor, and loss of all property rights. The criminal was subject to perpetual absolute disqualification from holding public office and subject to lifelong surveillance by the authorities. Id at 364 .

In a more recent case, Trop v Dulles, 356 US 86, 101 (1958), the Court found "that use of denationalization as a punishment [for desertion from the army during wartime] is barred by the Eighth Amendment. . . . It is a form of punishment more primitive than torture, for it destroys for the individual the political existence that was centuries in the development." In the most recent Supreme Court case on this issue, Hutto $v$ Finney, 437 US 678, 682 (1978), the Court found that harsh circumstances in prison isolation cells were cruel and 
the "status" of the offender; $;^{20}$ and 4) when a sentence is grossly disproportionate to the crime committed. ${ }^{21}$

The statute at issue in Hardwick did not involve the death penalty, inhumane or barbarous punishment, or punishment for status. ${ }^{22}$ Therefore, disproportionality is the only possible justification for striking down the statute on cruel and unusual punishment grounds. This conclusion is consistent with Justice Powell's reasoning in Hardwick, in which he compared Georgia's sodomy penalties with penalties for other crimes in Georgia ${ }^{23}$ and with the

unusual.

${ }^{20}$ In Robinson v California, 370 US 660 (1962), the Supreme Court struck down a California law that made it a criminal offense to be addicted to the use of narcotics. The Court held that "[t]o be addicted to the use of narcotics is said to be a status or condition and not an act." Id at 662. The Court went on to hold that, "a state law which imprisons a person thus afflicted as a criminal, even though he has never touched any narcotic drug within the State or been guilty of any irregular behavior there, inflicts a cruel and unusual punishment in violation of the Fourteenth Amendment." Id at 667.

Six years after Robinson, the Supreme Court clarified its position in Powell v Texas, 392 US 514 (1968) a case involving a Texas law that criminalized public intoxication. Powell was found to be a "chronic alcoholic" who was powerless not to drink. Id at 518. In spite of the fact that Powell could not control his own drinking, the Court held that the statute was constitutional because it did not punish Powell's status, but his physical act of public intoxication. "The State of Texas thus has not sought to punish a mere status, as California did in Robinson; nor has it attempted to regulate appellant's behavior in the privacy of his own home. Rather, it has imposed upon appellant a criminal sanction for public behavior ...." Id at 532.

22 Solem $v$ Helm, 463 US 277 (1983). A thorough analysis of this issue follows.

22 Some challengers of sodomy statutes claim that these laws do punish the status of being homosexual. See, for example, Comment, Constitutional Challenges to Sodomy Statutes in the Context of Homosexual Activity After Bowers v Hardwick, 32 SD L Rev 323, 338 (1987); Comment, The Right of Privacy and Other Constitutional Challenges to Sodomy Statutes, 15 Toledo L Rev 811, 863 (1984); Sandra J. Grove, Constitutionality of Minnesota's Sodomy Law, 2 Law \& Inequality 521, 551 (1984). Justice Blackmun made this argument in his dissent in Hardwick. 478 US at $202 \mathrm{n}$ 2. However, in Robinson and Powell, the Supreme Court drew the line between actual physical acts and status. No state sodomy statute punishes the status of being a homosexual, but only the physical act of sodomy. A homosexual may claim that he is driven to commit these criminal acts, but the Supreme Court rejected this argument in Powell. 392 US at 518, 532. Lower federal and state court cases have uniformly found that sodomy statutes punish specific acts and not status or desire. See, for example, Baker $v$ Wade, 774 F2d 1285, 1287 (5th Cir 1985) ("Though the conduct be the desire of the bisexually or homosexually inclined, there is no necessity that they engage in it"); People v Stevenson, 28 Mich App 538, 184 NW2d 541, 543 (1970) ("The statute proscribes overt conduct, not a particular mental condition or predisposition. The sentence imposed on such overt conduct is not cruel and unusual."); and Neville v State, $290 \mathrm{Md} \mathrm{364,} 430$ A2d 579, 581 (1981) ("The State here has . . . imposed a sanction for behavior it deems harmful or offensive to the sensibilities of a large segment of the community. This it is entitled to do under the Eighth Amendment . . ..").

2s Justice Powell claims that the penalty for sodomy is comparable, in terms of the possible sentence imposed, to that of aggravated battery, first degree arson, and robbery. Hardwick, 478 US at 197-98. 
penalties for sodomy imposed in other states. ${ }^{24}$ Such comparisons, we shall see, are important components of the Court's proportionality jurisprudence.

Though an early form of proportionality analysis figured most clearly in death penalty cases such as Gregg $v$ Georgia ${ }^{25}$ and Coker $v$ Georgia ${ }^{26}$ the doctrine really had its origins in Weems $v$ United States, ${ }^{27}$ a case involving inhumane punishment. A Philippine court $^{28}$ sentenced Weems to cadena temporal for falsifying public documents. Cadena temporal involved twelve to twenty years of hard labor in chains, permanent loss of property and citizenship rights, and surveillance by the public authorities for life. ${ }^{29}$ The Supreme Court explained that the Founders understood the Cruel and Unusual Punishment Clause primarily as a protection against barbarous punishments such as whippings and cutting off ears, ${ }^{30}$ but that the clause was intended to encompass new situations and contexts that the Framers could not have foreseen. "[A] principle, to be vital, must be capable of wider application than the mischief which gave it birth." 31 As part of its analysis, the Court compared the punishment of cadena temporal with punishments for other crimes in the same jurisdiction and with the punishments for forgery in other jurisdictions. ${ }^{32}$ This process of comparing sentences has become an integral part of current Supreme Court proportionality analysis.

\section{A. The Proportionality Trilogy}

In the 1980's, the Supreme Court decided three proportionality cases that dramatically increased the impact of the Eighth Amendment on legislative determinations of appropriate punishment. Although it is difficult, if not impossible, to harmonize the holdings of these cases, all three are valid law and are essential to an understanding of current proportionality analysis.

24 Justice Powell claims that "[a]mong those states that continue to make sodomy a crime, Georgia authorizes the longest possible sentences." Id at $198 \mathrm{n} 1$.

28428 US 153 (1976).

${ }^{26} 433$ US 584 (1977).

27217 US 349 (1910).

${ }^{28}$ Weems was a United States citizen since the Philippines was a United States territory at the time of the case.

29 Id at 364 .

so Id at 373 .

s1 Id at 373.

32 Id at 380 . 


\section{Rummel $v$ Estelle}

In Rummel $v$ Estelle, ${ }^{33}$ the Supreme Court upheld a Texas recidivist statute that mandated a life sentence with the possibility of parole for third conviction felons. ${ }^{34}$ The three felonies Rummel committed were relatively minor: fraudulent use of a credit card, passing a forged check, and obtaining money under false pretenses. The total theft from all three crimes was $\$ 229$. Nevertheless, Justice Rehnquist, writing for the Court, concluded that the Texas statute was constitutional because, in the absence of unique penalties such as cadena temporal or the death penalty, setting criminal punishments is a matter of legislative prerogative, and because it is difficult to develop objective judicial criteria to determine the proper length of a prison sentence. ${ }^{35}$

After analyzing many of the Court's earlier Eighth Amendment cases, including Weems and the death penalty cases, Justice Rehnquist went on to explain that objective judicial line-drawing was possible in Weems because of the obvious differences between cadena temporal and more traditional forms of imprisonment. $\mathrm{He}$ wrote, however, that "a more extensive intrusion into the basic line-drawing process that is pre-eminently the province of the legislature when it makes an act criminal would be difficult to square with the view expressed in Coker that the Court's Eighth Amendment judgments should neither be nor appear to be merely the subjective views of individual Justices." 36

In attempting to prove that his sentence was disproportionate to his crime, Rummel presented charts and tables to the Court indicating that he might have received a more lenient sentence in almost any other jurisdiction. ${ }^{37}$ The Court rejected this comparative analysis for two reasons. First, the Court noted that variables within sentencing statutes complicated any comparison of sentences actually given in different jurisdictions. It noted that since "parole is 'an established variation on imprisonment of convicted criminals,' . . . a proper assessment of 'Texas' treatment of

ss 445 US 263 (1980).

s4 At the time of Rummel, Texas's recidivist statute provided that "[w]hoever shall have been three times convicted of a felony less than capital shall on such third conviction be imprisoned for life in the penitentiary." Tex Penal Code Ann, art 63 (Vernon 1969).

ss Rummel, 445 US at 274.

so Id at 275.

${ }^{37}$ Rummel would have received the same sentence in two other states and the same sentence after four felonies in several other states. Some states required that one of the felonies be violent to support a life sentence, and some states left a life sentence after three felonies within the discretion of the judge. Id at 279-82. 
Rummel could hardly ignore the possibility that he will not actually be imprisoned for the rest of his life. . . . Another variable complicating the calculus is the role of prosecutorial discretion in any recidivist scheme." terjurisdictional analysis on federalism grounds: "Absent a constitutionally imposed uniformity inimical to traditional notions of federalism, some State will always bear the distinction of treating particular offenders more severely than any other State."39

In his dissenting opinion, Justice Powell took issue with the Court's conclusion that sentences between jurisdictions cannot be compared. He outlined three "objective" factors to be used in determining the proportionality of a proposed sentence to the crime committed: "(i) the nature of the offense, ... (ii) the sentence imposed for commission of the same crime in other jurisdictions, ... and (iii) the sentence imposed upon other criminals in the same jurisdiction." ${ }^{40} \mathrm{He}$ rejected as "cruelly ironic" the notion that such comparisons were rendered dubious by the possibility of parole that discounted the magnitude of a prisoner's sentence. ${ }^{41} \mathrm{He}$ further rejected the Court's invocation of federalism, arguing that any interstate differences must make way for constitutional norms. ${ }^{42}$ Justice Powell concluded that, although Rummel had committed criminal acts for which he could be punished and had been given a sentence that was not inherently barbarous, "the relationship between the criminal acts and the sentence is grossly disproportionate." ${ }^{48}$

\section{Hutto $v$ Davis}

In Hutto $v$ Davis, ${ }^{44}$ the Supreme Court reviewed a Virginia court sentence of forty years imprisonment and $\$ 20,000$ in fines imposed on the defendant for possession of nine ounces of marijuana with intent to distribute, and distribution. The district court, on habeas corpus review, held the punishment to be cruel and unusual..$^{45}$ An evenly divided Fourth Circuit, sitting en banc,

${ }^{38}$ Id at 280-81.

39 Id at 282.

10 Id at 295. The Supreme Court eventually adopted a slightly modified version of Powell's three factors in Solem $v$ Helm, 463 US 277 (1983). See text accompanying note 53.

4 Rummel, 445 US at 294.

12 Id at 303.

13 Id at 302.

14454 US 370 (1982).

45 Davis v Zahradnick, 432 F Supp 444, 453 (W D Va 1977). 
affirmed this ruling. ${ }^{46}$ In a per curiam opinion, the Supreme Court reversed, noting that it had "never found a sentence for a term of years within the limits authorized by statute to be, by itself, a cruel and unusual punishment." 7 Quoting from Rummel, the Court indicated that there was no way to compare the constitutionality of prison sentences of different lengths. "[T]he excessiveness of one prison term as compared to another is invariably a subjective determination, there being no clear way to make 'any constitutional distinction between one term of years and a shorter or longer term of years.' "48

Despite his belief that Hutto's sentence was significantly disproportionate, Justice Powell concurred in the judgment of the Court, stating that he "reluctantly conclude[d] that the court's decision in Rummel v. Estelle, is controlling on the facts before us." Justice Powell wrote that "[b]y comparison, Rummel's offenses-three minor frauds involving almost trifling sums of money-were far less serious [than Davis's]. Rummel's sentence, moreover, was more severe than Davis's. And Davis has been unable to show-by means of statutory comparisons-that his sentences suffer from a greater degree of disproportionality than Rummel's did."

\section{Solem v Helm}

In 1983 , in Solem $v$ Helm, ${ }^{51}$ another case involving a recidivist statute, the Supreme Court adopted a slightly modified version of the test that Justice Powell suggested in Rummel. Helm was convicted of passing a bad check, and also had six prior felony convictions: three convictions for third-degree burglary, and separate convictions for obtaining money under false pretenses, grand larceny, and third-offense driving while intoxicated. Under South Dakota's recidivist statute, he was sentenced to life imprisonment without the possibility of parole. In appealing the denial of a writ

16 Davis v Davis, 646 F2d 123 (4th Cir 1981) (en banc). The Supreme Court had originally remanded to the Fourth Circuit to reconsider the case in light of Rummel. Hutto $v$ Davis, 445 US 947 (1980).

17454 US at 372 (quoting Davis v Davis, 585 F2d 1226, 1229 (4th Cir 1978)).

18 Id at 373 (quoting Rummel, 445 US at 275).

19 Id at 375 (citation omitted).

so Id at 380 . Justice Powell concurred despite that fact that only five years after Davis's conviction, Virginia had reduced the maximum penalty for each of Davis's offenses from forty to ten years, thereby demonstrating a change of legislative opinion on the severity of the offenses.

s1 463 US 277 (1983). 
of habeas corpus to the Supreme Court, Helm claimed that his sentence was significantly disproportionate to the severity of his crimes.

Writing for the Court this time, Justice Powell held "as a matter of principle that a criminal sentence must be proportionate to the crime for which the defendant has been convicted." offered a test of proportionality that closely resembled the one he had first suggested in his dissent in Rummel:

When sentences are reviewed under the Eighth Amendment, courts should be guided by objective factors that our cases have recognized. First, we look to the gravity of the offense and the harshness of the penalty. ... Second, it may be helpful to compare the sentences imposed on other criminals in the same jurisdiction. . . . Third, courts may find it useful to compare the sentences imposed for commission of the same crime in other jurisdictions. ${ }^{53}$

The Court applied each part of this test to Helm's punishment and concluded that his sentence was significantly disproportionate to his crime and therefore prohibited by the Eighth Amendment. First, the Court noted that, for relatively minor criminal conduct, Helm had received the most severe sentence that the state could impose. ${ }^{54}$ Second, his sentence was the same as, or harsher than, sentences imposed in South Dakota for more serious crimes. ${ }^{55} \mathrm{Fi}-$ nally, his sentence was harsher than he would have received for the same offense in any other jurisdiction, except one. ${ }^{.6}$

Thus, Helm is the only case in which the Supreme Court has found a prison term, without other forms of punishment, to be disproportionate to the offense. The Helm proportionality test is controlling Supreme Court precedent, but Rummel and Hutto, in which the Court upheld prison sentences less that life without

32 Id at 290.

s3 Id at 290-92 (footnotes omitted).

s4 Since South Dakota did not allow capital punishment at this time, Helm's sentence was the most severe penalty the State could have imposed for any crime. In addition, none of Helm's crimes involved violence, and all involved minor amounts of money. Id at 297.

ss South Dakota authorized life sentences for murder, treason, first-degree manslaughter, first-degree arson, and kidnapping. On the second or third offense, the crimes of placing an explosive on an aircraft and rape were pumishable by life imprisonment, but life sentences were not authorized for a third offense of distribution of heroin or aggravated assault. Id at 298-99.

${ }^{56}$ Only Nevada also authorized a life sentence without parole for Helm's offense. Unlike South Dakota, however, Nevada left the parole decision to the judge's discretion. Helm would have received a lesser sentence in 48 of the 50 states. Id at 299-300. 
parole, must be considered limitations on the Court's holding in Helm. The relation between the punishment and the crime upheld in Rummel and Hutto thus form the minimum threshold of proportionality under the Eighth Amendment. ${ }^{.7}$

\section{Helm Proportionality and Sodomy Statutes}

Many commentators have criticized the Helm test as being nonobjective and readily manipulable. ${ }^{58}$ When one applies the test to sodomy statutes, the accuracy of this assessment becomes clear. A strong case can be made that Helm was wrongly decided and that Powell's "objective" test should never be used. However, even if one accepts the result in Helm and admits that there are times when the Helm test should be used, the test should not be used in analyzing crimes like sodomy for which there are no "objective" judicial factors with which to measure the various prongs of the test. In addition, in light of existing Supreme Court precedent, the Georgia sodomy statute in Hardwick cannot be struck down on proportionality grounds even under Powell's test.

\section{A. Gravity of Offense vs. Harshness of Penalty}

This prong of the Helm test is probably the most difficult to apply. In many ways the use of this prong begs the question of proportionality because it suggests no truly objective factors with which to weigh the gravity of an offense against the harshness of the penalty.

\section{Gravity of offense.}

The Court has failed to provide definitive standards with which to measure the gravity of an offense. The only available guidance is the rudimentary analysis used by the Court in Rummel and Helm. In Rummel, Justice Powell's dissenting opinion emphasized that the defendant's offenses were not very grave, in so far as none of the crimes involved injury, violence, or the threat thereof. ${ }^{59}$

sz For a complete discussion of this argument see section II.D.

${ }^{s 8}$ See, for example, Charles W. Schwartz, Eighth Amendment Proportionality Analysis and the Compelling Case of William Rummel, $71 \mathrm{~J}$ Crim L \& Criminol 378 (1980); Alexis M. Durham III, Weighing Punishments: A Commentary on Nevares-Muniz, $76 \mathrm{~J}$ Crim L \& Criminol 201 (1985); Note, Solem v. Helm: Proportionality Review of Recidivist Sentencing is Required by the Eighth Amendment, 33 DePaul L Rev 149 (1983); Note, Eighth Amendment Proportionality Analysis: The Limits of Moral Inquiry, 26 Ariz L Rev 1069 (1984); Recent Decisions, Solem v Helm, 22 Duquesne L Rev 1069 (1984).

Bo Rummel, 445 US at 295. 
In Helm, the Court expanded the violent/non-violent distinction in order to provide a more detailed description of the factors to be considered when judging the gravity of an offense. These factors include the presence or absence of violence or the threat of violence, the mens rea of the defendant, the occurrence of injury or the threat of injury, the magnitude of the crime (e.g., the degree of injury or amount of money stolen), and the defendant's motive in committing the crime. ${ }^{80}$ The Court concludes that this list "illustrates that there are generally accepted criteria for comparing the severity of different crimes on a broad scale."61

These criteria may work well for certain crimes, but they provide little guidance for distinguishing between the gravity of offenses that are nonviolent and lack quantifiable harm. Yet, society certainly can, and does, consider many such crimes serious. ${ }^{62}$ As the Court noted in Rummel, "the presence or absence of violence does not always affect the strength of society's interest in deterring a particular crime or in punishing a particular criminal."63 Also, distinctions based on the amount of money stolen are "subjective,' and therefore properly within the province of legislatures, not courts." Although the Court's holding in Helm could be interpreted as overruling the Rummel Court's statements on the subjective nature of the gravity of an offense, the reasoning of Rummel still creates a valid challenge to Powell's listed factors.

Justice Powell admitted "the difficulties courts face in attempting to draw distinctions between similar crimes."65 $\mathrm{He}$ explained that "[a]pplication of [the proportionality test] assumes that courts are competent to judge the gravity of an offense, at least on a relative scale. In a broad sense this assumption is justified, and courts traditionally have made these judgments-just as legislatures must make them in the first instance."66 Here, Justice Powell points to the real problem behind asking judges to determine the seriousness of specific crimes once the broad scale analysis is complete: such an analysis should be reserved for democratically elected legislatures, not appointed judges who have little

so Helm, 463 US at $292-93$.

11 Id at 294.

${ }^{82}$ Many crimes, such as fraud and deception, sex crimes like adultery or public indecency, and drug crimes involving possession or distribution, do not involve factors such as violence or weapons and yet often involve heavy penalties.

ss Rummel, 445 US at 275 .

${ }^{64}$ Id at 275-76.

os Helm, 463 US at 294.

${ }^{88}$ Id at 292. 
basis for their decision, except their own personal views on the seriousness of the crime.

The above arguments show that the gravity of the offense prong of the Helm proportionality test is ambiguous as a general matter. An analysis of sodomy statutes using this prong also reveals the weakness of the Helm Court's criteria as applied to a concrete offense. Consensual sodomy does not involve violence, weapons, or injury-the main criteria suggested by Powell to evaluate proportionality. Yet these are not the only factors that justify the imposition of penal sanctions. In addition to violent crimes, society chooses to prohibit a large class of so-called victimless activities largely for moral and social reasons. Crimes such as sodomy, bootlegging, prostitution, and drug possession can be considered "victimless," but they are outlawed primarily because such activities are believed to be harmful to society in general. The Helm formulation does not take into account such rationales for punishment.

Twenty-seven of the fifty-one jurisdictions in the United States currently criminalize sodomy. ${ }^{67}$ Although some of these statutes are very old, nearly all of them have been recently amended or reenacted, indicating a legislative reaffirmation of the policies they embody. ${ }^{68}$ Thus, there is at least a presumption that

67 The statutes in effect are found at: Ala Code § 13A-6-65(a)(3) (1982); Ariz Rev Stat Ann §§ 13-1411, 13-1412 (West, Supp 1987); Ark Stat Ann § 5-14-122 (1987); DC Code § 223502 (1981); Fla Stat Ann § 800.02 (West 1976); Ga Code Ann § 16-6-2 (Michie 1988); Idaho Code § 18-6605 (1987); Kan Stat Ann § 21-3505 (1981); Ky Rev Stat Ann § 510.100 (Baldwin 1985); La Rev Stat Ann § 14:89 (West 1986); Md Ann Code art 27, §§ 553-554 (1982); Mass Ann Laws ch 272, § 34 (Michie/Law Co-op 1980); Mich Comp Laws Ann § 750.158 (West 1968); Minn Stat Ann § 609.293 (West 1987); Miss Code § 97-29-59 (1972); Mo Ann Stat $\S 566.090 .1(3)$ (Vernon 1979); Mont Code Ann § 45-5-505 (1987); Nev Rev Stat $\S$ 201.190 (1987); NY Penal Law § 130.38 (McKinney 1987); NC Gen Stat § 14-177 (1988); 21 Okla Stat Ann $\S 886$ (West 1983); RI Gen Laws § 11-10-1 (1970); SC Code Ann § 16-15-120 (Law Co-op 1985); Tenn Code Ann § 39-2-612 (1982); Tex Penal Code Ann § 21.06 (Vernon 1974); Utah Code Ann § 76-5-403 (1988); Va Code $\S 18.2-361$ (1988).

os Twelve statutes have been recently amended and eight recently enacted or reenacted. The dates of enactment or most recent amendment for all twenty-seven jurisdictions criminalizing sodomy follow. Alabama reenacted in 1977 (1977 Ala Acts, No 607, p 812, § 2318); Arizona amended in 1985 (1985 Ariz Sess Laws, ch 364, § 22); Arkansas reenacted in 1977 (1977 Ark Acts, No 828, \& 1); District of Columbia reenacted in 1948 (62 Stat 347 (1948)); Florida reenacted in 1971 (1971 Fla Laws, ch 71-136, § 778); Georgia reenacted in 1968 (1968 Ga Laws, p 1249, § 1); Idaho amended in 1972 (1972 Idaho Sess Laws, ch 336, § 1, p 844); Kansas amended in 1969 (1969 Kan Sess Laws, ch 180); Kentucky reenacted in 1974 (1974 Ky Acts, ch 406, § 90); Louisiana amended in 1982 (1982 La Acts, No 703, § 1) Maryland amended in 1976 (1976 Md Laws, ch 573, $\S$ 3); Massachusetts legislative history unclear (Mass Ann Laws ch 272, § 34 (Michie/Law Co-op 1980)); Michigan amended in 1952 (1952 Mich Pub Acts, No 73, § 1) Minnesota amended in 1984 (1984 Minn Laws, ch 628, art 3, § 11); Mississippi amended in 1942 (1942 Miss Laws § 2413); Missouri enacted in 1977 
public attitudes support sodomy statutes in over half of the jurisdictions in the United States. The Helm test gives no weight to these religious, moral, and social attitudes. Where the immorality of conduct is one of the bases for criminal sanctions, the Helm Court's "objective criteria" are of little help in determining the gravity of the crime.

Each state's sodomy statute is based on the collected views of individual citizens about the morality of the crime. Since legislatures are composed of elected representatives of the people and contain more individuals from a more diverse cross section of the jurisdiction than the courts, they are in a better position to implement the public will than are judges, who must rely on their own moral sentiment measured by Powell's vague criteria. Legislatures are much better equipped to draw moral lines and measure public sentiment. ${ }^{68}$ A judge would be assuming unconstitutional powers if she suggested that she had discovered that a certain law was not supported by a majority of the populace and thus would not be enforced. Constitutional laws that do not reflect the will of the majority should be changed by the legislature, not by individual judges.

\section{Harshness of penalty.}

The Helm proportionality test requires a comparison of the harshness of the penalty imposed with the gravity of the offense. Once again, there are serious line drawing problems. Obviously some sentences are more severe than others, but how can judges determine which sentence violates the Eighth Amendment and which does not? And even if judges could determine the relative gravity of various crimes, how would they convert such gravities to years? It is one thing to distinguish between a life sentence without possibility of parole and a life sentence with parole, as the Court did in Helm and Rummel; $;^{70}$ it is another to distinguish be-

(1977 Mo Laws, SB No 60, p 662, § 1); Montana amended in 1981 (1981 Mont Laws, § 7, ch 198); Nevada amended 1977 (1977 Nev Stat, 866, 1632); New York enacted 1965 (1965 NY Laws ch 1038, § 2); North Carolina amended in 1979 (1979 NC Sess Laws, ch 760, § 5); Oklahoma enacted in 1910 (1910 Okla Sess Laws, $\S 2444$ ); Rhode Island legislative history unclear (RI Gen Laws § 11-10-1 (1970)); South Carolina legislative history unclear (SC Code Ann § 16-15-120 (Law Co-op 1985)); Tennessee amended in 1982 (1982 Tenn Pub Acts (Adj S), ch 568, § 3); Texas enacted in 1973 (1973 Tex Gen Laws, 63rd Leg, ch 399); Utah amended in 1983 (1983 Utah Laws, ch 88, § 21); Virginia amended in 1981 (1981 Va Acts, ch 397).

69 See quote from Justice Burger in Helm, quoted in text at note 72 .

${ }^{70}$ A prisoner sentenced to life without parole will certainly-short of a commutation by 
tween terms of years. In Helm, the Court admitted that drawing constitutional lines between different sentences for periods of years would be difficult: "It is clear that a 25-year sentence generally is more severe than a 15-year sentence, but in most cases it would be difficult to decide that the former violates the Eighth Amendment while the latter does not."

Chief Justice Burger argued in Helm that judges are not capable of distinguishing between different sentences for repeat offenders. "Nor, as this case well illustrates, are we endowed with Solomonic wisdom that permits us to draw principled distinctions between sentences of different length for a chronic 'repeater' who has demonstrated that he will not abide by the law. . . . Legislatures are far better equipped than we are to balance the competing penal and public interests and to draw the essentially arbitrary lines between appropriate sentences for different crimes."72

In addition to this language from $\mathrm{Helm}$, the Court stated in Davis that "the excessiveness of one prison term as compared to another is invariably a subjective determination, there being no clear way to make 'any constitutional distinction between one term of years and a shorter or longer term of years." "73 In light of these statements, Justice Powell's argument in Hardwick that a sodomy sentence for an ordinary term of years may be unconstitutional seems ill conceived. Existing sodomy statutes provide for sentences from one month to twenty years. ${ }^{74}$ Short of holding all sodomy penalties unconstitutional, drawing constitutional lines between these sentences for periods of years would be too difficult to justify.

\section{B. Sentences For Other Crimes in The Same Jurisdiction}

Under the second prong of the Helm test, a court compares the sentence for the crime involved with the sentence for other crimes in the same jurisdiction. It is unclear exactly what such a comparison proves. Suppose the penalty for sodomy is more severe than the penalty for some other crime. This does not necessarily mean that the penalty for sodomy is too high, but merely reflects the judgment of the state that sodomy should be punished more

the governor of a state-spend the rest of her life in prison. A prisoner sentenced to twenty years might be released on parole in a much shorter period of time.

71 Id at 294 (footnote omitted).

72 Id at 314 (Burger dissenting).

73 Davis, 445 US at 373.

7 See text at notes $110-21$. 
severely than some other crime. In Rummel, the Court discussed the difficulty of this type of comparison, stating that, "[o]ther crimes, of course, implicate other societal interests, making any such comparison inherently speculative. ... Once the death penalty and other punishments different in kind from fine or imprisonment have been put to one side, there remains little in the way of objective standards for judging whether or not a life sentence imposed under a recidivist statute for several separate felony convictions not involving 'violence' violates the cruel-and-unusualpunishment prohibition of the Eighth Amendment."75

The implication of this prong of the Helm test is that similar crimes should always have similar penalties, but the Helm Court gives no guidance as to which other crimes are appropriate to use in comparing sentences. Some guidance may be found in Powell's comparison, in Hardwick, of the sentence provided for in Georgia's sodomy statute with the sentences provided in Georgia for three other crimes. Powell explained that the sentence in Georgia for sodomy was comparable to the sentence imposed for aggravated battery, first-degree arson, and robbery. ${ }^{76}$ The potential range of sentences for all these crimes is one to twenty years. ${ }^{77}$

The weakness in this analysis is that a judge could pick any crimes that she thinks are more serious than sodomy and compare the sentences involved. This process could be easily manipulated to make any crime appear proportionate or disproportionate. For example, if Justice Powell would have compared sodomy with murder (death or life imprisonment), highjacking (death or life), feticide (life), treason (death or fifteen years to life), or selling cocaine (ten year minimum), he would have concluded that the sentences were not similar and thus the sentence for sodomy was proportionate. ${ }^{78}$

In fact, if Powell had compared the same three crimes he compared in Hardwick with the sentence for sodomy in Rhode Island (which also provides a maximum twenty year sentence), he probably would have reached the conclusion that the sodomy statute was proportionate. In Rhode Island, assault has a penalty similar to that for sodomy, one to twenty years. However, the penalties for

${ }^{75}$ Rummel, 445 US at 282-283, n 27.

${ }^{76}$ Hardwick, 478 US at 198.

77 Sodomy: Ga Code Ann $\S 16-6-2$ (Michie 1988); aggravated battery: id at § 16-5-24; first-degree arson: id at $\S 16-7-60$; robbery: id at $\S 16-8-40$.

${ }^{78}$ Murder: Ga Code Ann § 16-5-1 (Michie 1988); highjacking: id at § 16-5-44; feticide: id at $\S 16-5-80$; treason: id at $\S 16-11-1$; selling cocaine: id at $\S 16-13-31$. 
arson and robbery are much harsher, with sentences of five years to life. ${ }^{79}$ Thus, it appears that by comparing the same crimes in Rhode Island that Powell compared in Georgia, a judge could conclude that sodomy was proportionate because "more serious" crimes had harsher penalties. ${ }^{80}$

Powell's comparison of sentences for crimes that he considers more serious is troubling primarily because it is so easily manipulated. It is very difficult to compare crimes that implicate different societal interests. A better comparison than that between more and less serious crimes is that between crimes that are similar enough to be grouped in the same broad categories.

In the case of sodomy laws, other sexual or "moral" crimes may provide some guidance. For example, adultery and sodomy share many of the same characteristics, although there are real distinctions between the two crimes. Adultery and sodomy both involve sexual acts, are consensual, and can be performed in the privacy of the home. On the other hand, sodomy involves what many states consider an "unnatural" sexual act particularly between adults of the same sex, while adultery is never described as unnatural and involves adults of opposite sexes. That a judge will not know how to determine which distinctions are relevant highlights the difficulty of implementing the Helm test.

A comparison of adultery and sodomy statutes shows that a majority of jurisdictions consider sodomy to be a more serious crime than adultery. One state provides a higher penalty for adultery than for sodomy. ${ }^{\mathbf{8 1}}$ Five states provide exactly the same penalty for both crimes. ${ }^{82}$ Thirteen jurisdictions provide lower penalties for adultery than for sodomy. ${ }^{83}$ Eight states punish sodomy,

79 Assault: RI Gen Laws § 11-5-1 (1970); arson: id at § 11-4-2; robbery: id at § 11-39-1.

${ }^{80}$ In Massachusetts (the only other state providing for a twenty year maximum sentence for sodomy), the maximum sentence for these three crimes are: arson - twenty years (Mass Ann Laws ch 266, \& 1 (Michie/Law Co-op 1980); assault - ten years (id at ch 265, § $15)$; robbery - life (id at ch $265, \S 17$ ). Since one sentence is lighter, one is the same, and one is much harsher than the sentence for sodomy, it is unclear what a judge should conclude under Justice Powell's test.

s1 Utah (adultery: 1 year, Utah Code Ann § 76-7-103 (1978), sodomy: 6 months, id at § 76-5-403 (1978)).

${ }^{82}$ Arizona (Ariz Rev Stat Ann $\$ \S 13-1408,13-1411,13-1412$ (West, Supp 1987)), Florida (Fla Stat Ann $\S \S 798.01,800.02$ (West 1976)), Michigan (Mich Comp Laws Ann $\S \S 750.30$, 750.158 (West 1968)), Minnesota (Minn Stat Ann $\S \S 609.36,609.293$ (West 1987)), and New York (NY Penal Laws §§ 255.17, 130.38 (McKinney 1987)).

ss Alabama (adultery: 6 months, Ala Code $\$ 13 \mathrm{~A}-13-2$ (1982), sodomy: 1 year, id at $\$$ 13A-6-65(a)(3)); District of Columbia (adultery: 1 year, DC Code $\$ 22-301$ (1981), sodomy: 10 years, id at $\S 22-3502$ ); Georgia (adultery: 1 year Ga Code Ann $\S 16-6-19$ (Michie 1988), sodomy: 20 years, id at § 16-6-2); Idaho (adultery: 3 years maximum, Idaho Code $\S 18-6601$ 
but do not punish adultery. ${ }^{84}$ Seven states punish adultery, but provide no penalty for sodomy. ${ }^{85}$

The difference in descriptions between sodomy and adultery in state statutes demonstrates that the reason many jurisdictions consider sodomy a more serious crime than adultery is that sodomy is deemed more morally and socially offensive. State statutes often refer to sodomy as the crime against nature ${ }^{86}$ the infamous crime against nature, ${ }^{87}$ the abominable and detestable crime against nature, ${ }^{88}$ as an unnatural and lascivious act, ${ }^{89}$ or deviate sexual behavior, ${ }^{30}$ without using similar adjectives to describe adultery.

The three states that authorize the longest sentences for sodomy (twenty years) provide for only a one or three year maximum sentence for adultery. ${ }^{91}$ Under Powell's test, the penalty for sodomy in these states would probably be held disproportionate following such a comparison. However, if the penalties for sodomy are

(1987), sodomy: 5 years minimum, id at $\S 18-6605$ ); Kansas (adultery: 1 month, Kan Stat Ann § 21-3507 (1981), sodomy: 6 months, id at § 21-3505); Maryland (adultery: \$10 fine, Md Ann Code art 27, 4 (1987), sodomy: 10 years, id at art 27, § 553); Mississippi (adultery: 6 months Miss Code Ann § 97-29-1 (1972), sodomy: 10 years, id at § 97-29-59); North Carolina (adultery: 6 months, NC Gen Stat § 14-184 (1988), sodomy: 10 years, id at $\S 14-177$ ); Oklahoma (adultery: 5 years, 21 Okla Stat Ann, $\S 872$ (West 1983), sodomy: 10 years, id at $\S$ 886); Rhode Island (adultery: 1 year, RI Gen Laws $\$ 11-6-2$ (1970), sodomy: 20 years, id at $\S$ 11-10-1); South Carolina (adultery: 1 year, SC Code Ann $\$ 16-15-60$ (Law Co-op 1985), sodomy: 5 years, id at $\S 16-15-120$ ); Virginia (adultery: $\$ 100$ fine, Va Code $\S 18.2-365$ (1982), sodomy: 5 years, id at $\S 18.2-361$ ).

${ }^{84}$ Arkansas (Ark Stat Ann § 5-14-122 (1987)), Kentucky (Ky Rev Stat Ann § 510.100 (Baldwin 1985)), Louisiana (La Rev Stat Ann § 14:89 (West 1986)), Missouri (Mo Ann Stat $\S 566.090 .1(3)$ (Vernon 1979)), Montana (Mont Code Ann § 45-5-505 (1987)), Nevada (Nev Rev Stat $\S 201.190$ (1987)), Tennessee (Tenn Code Ann $\S 39-2-612$ (1982)), and Texas (Tex Penal Code Ann $\S 21.06$ (Vernon 1974)).

${ }^{85}$ Colorado (Colo Rev Stat § 18-6-501 (1986)), Connecticut (Conn Gen Stat Ann § 53a81 (West 1985)), Mlinois (Ill Ann Stat ch 38 §§ 11-7 (Smith-Hurd 1979)), Nebraska (Neb Rev Stat § 28-704 (1985)), New Hampshire (NH Rev Stat Ann $\S 645: 3$ (Equity 1986)), West Virginia (W Va Code $\S 61-8-3$ (1984)), and Wisconsin (Wis Stat Ann $\S 944.16$ (West 1982)).

${ }^{86}$ See, for example, Louisiana (unnatural carnal copulation) (La Rev Stat Ann § 14:89 (West 1986)), North Carolina (NC Gen Stat § 14-177 (1986)), and Tennessee (Tenn Code Ann $\S 39-2-612$ (1982)).

${ }^{87}$ Arizona (Ariz Rev Stat Ann $\S 13-1411,13-1412$ (West, Supp 1987)) and Idaho (Idaho Code § 18-6605 (1987)).

${ }^{88}$ Massachusetts (Mass Ann Laws ch 272, $\$ 34$ (Michie/Law Co-op 1980)), Michigan (Mich Comp Laws Ann § 750.158 (West 1968)), Mississippi (Miss Code Ann $\$ 97-29-59$ (1972)), Oklahoma (21 Okla Stat Ann, $§ 886$ (West 1983)), and Rhode Island (RI Gen Laws § 11-10-1 (1970)).

89 Florida (Fla Stat Ann $\S 800.02$ (West 1976)).

so Montana (Mont Code Ann § 45-5-505 (1987)).

81 Georgia (Ga Code Ann § 16-6-19 (Michie 1988)), Massachusetts (Mass Ann Laws ch 272, § 14 (Michie/Law Co-op 1980)), and Rhode Island (RI Gen Laws § 11-6-2 (1970)). 
compared with the penalties for other, similar crimes, the penalties are probably not disproportionate under Powell's test. In Georgia, for instance, incest is punishable by up to twenty years in prison, ${ }^{\mathbf{2}}$ bigamy by up to ten years, ${ }^{93}$ bestiality by up to five years, ${ }^{94}$ and fornication by the same one year penalty as adultery. ${ }^{95}$ These crimes, because of their deviant sexual basis, are more easily compared to sodomy than violent crimes such as robbery, arson or assault.

In Rhode Island, which also allows up to twenty years imprisonment for sodomy, ${ }^{96}$ incest is punishable by ten years imprisonment, ${ }^{97}$ pandering by five years, ${ }^{98}$ bigamy by five years, ${ }^{99}$ and fornication by a $\$ 10$ fine. ${ }^{100}$ In Massachusetts, the final state which allows up to twenty years imprisonment for sodomy, ${ }^{101}$ incest is punishable by twenty years in prison, ${ }^{102}$ polygamy by five years, ${ }^{103}$ bestiality by twenty years, ${ }^{104}$ and fornication by three months. ${ }^{105}$ Since judges have no guidelines beyond general characteristics to determine whether a sentence is proportionate, a judge could easily use similarities between sexual or moral crimes to justify the high penalties for sodomy in Georgia, Massachusetts, and Rhode Island. In contrast, a Rhode Island judge could conclude that sodomy, incest, pandering, bigamy, and fornication are so similar they should all be punished by a $\$ 10$ fine. This possible disparity in results again helps to emphasize the difficulty of challenging legislatively determined sentences in the courts and suggests that only the legislature is equipped to determine the relative severity of arguably similar crimes.

\section{The Same Crime in Other Jurisdictions}

The third prong of the Helm test requires comparison of sentences imposed for the same crime in other jurisdictions. A dis-

${ }^{92} \mathrm{Ga}$ Code Ann $\S 16-6-22$ (Michie 1988).

${ }^{93} \mathrm{Id}$ at $\$ 16-6-20$.

of Id at $\$ 16-6-6$.

os Id at \$ 16-6-18.

s6 RI Gen Laws § 11-6-2 (1970).

97 Id at \$ 11-6-4.

${ }^{83}$ Id at § 11-34-1.

00 Id at $\$ 11-6-1$.

100 Id at $\S 11-6-3$.

${ }_{101}$ Mass Ann Laws ch 272, § 34 (Michie/Law Co-op 1980).

${ }^{102}$ Id at ch $272, \S 17$.

10 Id at ch $272, \S 15$.

${ }^{104}$ Id at ch $272, \S 34$.

${ }^{105}$ Id at ch 272, § 18. 
parity in sentences between jurisdictions was part of the Court's justification for finding Helm's sentence unconstitutional. $\mathrm{He}$ "could have received a life sentence without parole for his offense in only one other state." 106

However, comparing sentences among jurisdictions is difficult, if not impossible. Dissenting in Helm, Chief Justice Burger levelled a persuasive double-barrelled attack against such comparisons. First, he said that the interjurisdictional comparison ignores differing parole statutes in the various states. "[One] reason why comparison between the recidivist statutes of different states is inherently complex is that some states have comprehensive provisions for parole and others do not." ${ }^{107}$ This is true for all prison sentences, not just recidivist statutes. It would be very difficult to compare accurately one state's twenty year sentence with another state's ten year sentence if these states have different parole policies, particularly because parole policies often involve a great deal of discretion.

Burger's second reason for rejecting the comparison of sentences between jurisdictions is even more persuasive: "Perhaps most important, such comparisons trample on fundamental concepts of federalism. Different states surely may view particular crimes as more or less severe than other states. Stealing a horse in Texas may have different consequences and warrant different punishment than stealing a horse in Rhode Island or Washington, D.C." 108

This reasoning clearly applies to sodomy statutes. Different jurisdictions obviously feel differently about the seriousness of sodomy (as evidenced by the various punishments allowed). When such differences exist, the local legislature can best determine the moral views of the local populace and can write the penal statutes accordingly. To ignore the differences among the states would be to ignore the federalist nature of the Constitution:

[E]ven if the punishment ... . were to exceed that which he would have received in any other state, "that severity hardly would render [his] punishment 'grossly disproportionate' to his offenses or to the punishment he would have received in the other States. . . . Absent a constitutionally imposed uniformity inimical to traditional notions of federalism, some

${ }^{106} \mathrm{Helm}, 463$ US at 299, (quoting Helm v Solem, 684 F2d 582, 586 (8th Cir 1982)).

107 Id at 309 (Burger dissenting).

108 Id. Justice Rehnquist made these same arguments in his majority opinion in Rummel. See text at notes $39-40$. 
State will always bear the distinction of treating particular offenders more severely than any other State"109

Justice Powell did not explain the impact of a difference in sentences among the jurisdictions. He seems to suggest that some objective national proportionality standard for each crime is possible. However, Powell does not explain how to determine just where this permissible range of sentences lies. In sodomy statutes, there are differences between the states, but the Helm Court does not explain what happens when a convict could receive the same sentence in one, two, or a number of states, or a slightly lighter sentence in a majority of states. Thus, this prong of the test provides very little guidance.

There are vast differences between state sodomy statutes. One state provides a minimum penalty of five years imprisonment for sodomy with an open maximum penalty, which theoretically allows a life sentence. ${ }^{110}$ Other maximum sentences are: three jurisdictions with twenty years, ${ }^{111}$ two jurisdictions with fifteen years, ${ }^{112}$ six jurisdictions with ten years, ${ }^{113}$ one state with six years, ${ }^{114}$ three states with five years, ${ }^{116}$ five states with one year, ${ }^{116}$ two states with six months, ${ }^{117}$ one state with three months, ${ }^{118}$ one state with two months, ${ }^{119}$ one state with one month, ${ }^{120}$ and one state with a fine, but no prison sentence. ${ }^{121}$ The remaining jurisdictions do not penalize consensual sodomy.

These statistics can be manipulated in a variety of ways. Among those states that penalize sodomy, the average maximum

109 Id (emphasis in original), quoting Rummel, 445 US at 281-282.

"10 Idaho (Idaho Code § 18-6605).

11 Georgia (Ga Code Ann § 16-6-2), Massachusetts (Mass Ann Laws ch 272, § 34), and Rhode Island (RI Gen Laws § 11-10-1).

112 Tennessee (Tenn Code Ann § 39-2-612) and Michigan (Mich Comp Laws Ann § 750.158).

113 District of Columbia (DC Code Ann § 22-3502), Maryland (Md Ann Code art 27, §§ 553-554), Mississippi (Miss Code Ann § 97-29-59), Montana (Mont Code Ann § 45-5-505), North Carolina (NC Gen Stat § 14-177), and Oklahoma (21 Okla Stat Ann, § 886).

114 Nevada (Nev Rev Stat § 201.190).

${ }^{113}$ Louisiana (La Rev Stat Ann § 14:89), South Carolina (SC Code Ann § 16-14-120), and Virginia (Va Code Ann § 18.2-361).

"16 Alabama (Ala Code § 13A-6-65(a)(3)), Arkansas (Ark Code Ann § 5-14-122), Kentucky (Ky Rev Stat $\S 510.100$ ), Minnesota (Minn Stat Ann $\S 609.293$ ), and Missouri (Mo Ann Stat § 566.090.1(3)).

117 Kansas (Kan Stat Ann § 21-3505) and Utah (Utah Code Ann § 76-5-403).

118 New York (NY Penal Law § 130.38).

119 Florida (Fla Stat Ann § 800.02).

120 Arizona (Ariz Rev Stat Ann § 13-1411).

121 Texas (Tex Penal Code Ann \$ 21.06). 
sentence is seven years. ${ }^{122}$ Does this mean that sentences within a range of seven years are constitutional, but sentences outside that range are not? The average maximum sentence among all jurisdictions including those that don't penalize sodomy, is four years. ${ }^{123}$ Does this mean that four years is the appropriate constitutional standard? The average of the highest and lowest sentence is ten years, ${ }^{124}$ and the specific maximum sentence allowed by the most states is also ten years. ${ }^{125}$ Does this mean that all states must adopt sentences hovering near the ten year level? Is it possible for a court to hold that a ten year sentence is constitutional, but a twenty year sentence is not? Helm does not answer these questions. Statistics are almost useless in determining whether the outer limits of the various sentences constitute cruel and unusual punishment. The Helm Court's admission that courts would have a difficult time finding that a twenty-five year sentence violates the Eighth Amendment, while a fifteen year sentence does not, ${ }^{126}$ is particularly applicable here.

The ultimate conclusions from application of all three prongs of the Helm proportionality test to sodomy are: First, the test is inherently non-objective since different judges (and different people) have widely varying beliefs about the offensiveness of sodomy. Second, there is no clear way to compare sentences for sodomy in different jurisdictions or the sentences for other crimes in the same jurisdiction. All this points to the fact that legislatures are better equipped to make these determinations than courts.

\section{Applying Supreme Court Precedent to Sodomy}

Existing Supreme Court proportionality precedents provide no support for the assertion that sodomy statutes allow cruel and unusual punishment. The Helm case simply holds that a life sentence without the possibility of parole is cruel and unusual punishment

122 This figure is obtained by adding the maximum sentences together, assuming that Idaho's indeterminate sentence is the equivalent of a twenty year maximum sentence, and dividing by twenty seven (the number of jurisdictions punishing sodomy).

${ }^{123}$ This figure is obtained by adding the maximum sentences together, assuming that Idaho's indeterminate sentence is the equivalent of a twenty year maximum sentence, and dividing by fifty one.

${ }^{124}$ Assuming that Idaho's indeterminate sentence is never higher than twenty years, the average of the highest sentence (twenty years) and the lowest sentence (no penalty) is ten years.

${ }^{125}$ Six states provide for a ten year maximum sentence. The next most frequently allowed penalty is one year, provided in five states.

${ }^{128} \mathrm{Helm}, 463$ US at 294. 
after conviction for seven "minor" felonies. It is critical to recognize that the Court's decision in Helm did not overrule Rummel. Instead, the Helm Court took pains to distinguish the sentence administered in Rummel. ${ }^{127}$ "[Helm's] sentence [life imprisonment without parole] is far more severe than the life sentence we considered in Rummel v. Estelle. Rummel was likely to have been eligible for parole within 12 years of his initial confinement, a fact on which the Court relied heavily. ... Helm's sentence is the most severe punishment that the State could have imposed on any criminal for any crime." ${ }^{28}$ Thus, the Supreme Court held in relation to recidivist statutes that life imprisonment without parole is unconstitutional, but that life imprisonment with the chance for parole does not violate the Eighth Amendment.

The Helm decision also left the holding in Davis intact. In his concurring opinion in Davis, Powell himself concluded that the holding in Rummel required the sentence in Davis to be upheld.129 "Rummel's sentence, moreover, was more severe than Davis'. And Davis has been unable to show-by means of statutory comparisons-that his sentences suffer from a greater degree of disproportionality than Rummel's did."130 Thus, according to Powell's analysis, courts must uphold any sentences that are less "disproportionate" than the sentence upheld in Rummel. The combination of these three Supreme Court holdings creates a threshold of disproportionality for finding a punishment cruel and unusual. If a sentence imposed is less disproportionate than Rummel's, the punishment is constitutional. ${ }^{131}$

Therefore, the proportionality of sodomy penalties must be compared with the proportionality of Rummel's sentence. The crime of sodomy at least arguably approaches the seriousness of the monetary fraud crimes involved in Rummel. Under Powell's factors in Rummel and Helm, ${ }^{132}$ sodomy and monetary fraud are both nonviolent, involving no threat of physical injury. Moreover, the magnitude of Rummel's crime was small, involving a total of

127 Id at 300-303.

${ }^{128}$ Id at 297 (footnote omitted).

129 Davis, 454 US at 375.

130 Id at 380.

131 Lower federal courts have followed and narrowed this threshold test. For example, in Holley v Smith, 792 F2d 1046 (11th Cir 1986), the court held that life imprisonment without parole under a recidivist statute requiring four felonies, only one of which had to be serious, is constitutional.

The Supreme Court has not yet ruled on the constitutionality of a sentence that lies somewhere between the sentence imposed in Helm and the one imposed in Rummel.

132 See text at notes 59-60. 
only $\$ 229$. Obviously, monetary fraud is not consensual, but the average punishment allowed for sodomy (ten years with the possibility of parole $)^{133}$ is substantially lower than the sentence imposed in Rummel for fraud (life imprisonment with the possibility of parole). Thus, current sodomy statutes do not impose cruel and unusual punishment because the punishments they provide are more proportionate than the punishment upheld in Rummel.

The proportionality of sodomy punishments can also be compared with the proportionality of Davis's punishment. Sodomy can be broadly grouped in the same category with the crime of drug possession with intent to distribute in Davis: both crimes are nonviolent and consensual. But, the average sentence for sodomy in the United States is half the length of the sentence upheld in $D a$ vis. The sentences imposed under even the most severe sodomy statutes are more proportionate than the sentence held constitutional in Davis. Ultimately, applying existing precedent, imprisonment for sodomy, even up to twenty years, is not more disproportionate than the sentences upheld for other crimes.

\section{DoRmant SoDomy Laws}

A final issue, important to a complete understanding of cruel and unusual punishment and sodomy statutes, is the utility of dormant sodomy laws. People are seldom, if ever, fully prosecuted under sodomy statutes. In Hardwick, the state conceded that "there had been no reported decision involving prosecution for private homosexual sodomy under this statute for several decades."134 The age and relative infrequency of sodomy cases in other jurisdictions suggests that the situation in Georgia is not atypical. In addition, almost all the reported cases involving sentences for sodomy also involve punishment for other crimes like rape, forcible sodomy, or public indecency. ${ }^{135}$

In a footnote to his concurring opinion in Hardwick, Justice Powell seems to point to the lack of enforcement of sodomy statutes as another ground for finding cruel and unusual punishment. ${ }^{136}$ Justice Powell might argue that judges, prosecutors, and police no longer enforce sodomy statutes because they and the public recognize that the statutes are wrong or bad. There are,

\footnotetext{
${ }^{133}$ See note 124 and accompanying text.

${ }^{134}$ Hardwick, 478 US at $198 \mathrm{n} 2$.

${ }^{135}$ See the decisions cited in section IV.

138 "The history of nonenforcement suggests the moribund character today of laws criminalizing this type of private, consensual conduct." Hardwick, 478 US at 198 n 2.
} 
however, several alternative explanations for this lack of enforcement. States do not enforce sodomy statutes, and similar laws such as adultery statutes, because of the great difficulty of investigating every bedroom in the jurisdiction to determine that prohibited acts are not taking place. In addition to lack of personnel, it would be very difficult to show probable cause for these searches. Another explanation is that public resources are, and probably should be, used to police more serious crimes involving violence or loss of life.

Are sodomy statutes unenforced because they are considered cruel and unusual or because of the alternative reasons suggested above? One important piece of evidence is that states do not enforce their sodomy statutes regardless of how long their penalty is; enforcement is not related to the length of the sentence. If the severity of the sentence were the reason sodomy statutes were not enforced, one would expect enforcement patterns to differ from state to state.

Even though they are unenforced, sodomy statutes may reflect a state's determination of its moral values. The recent amendment or reenactment of so many sodomy laws in the face of continued nonenforcement underscores this possibility. ${ }^{137}$ Thus, these statutes may serve an important function even if unenforced. Given that the sentences for sodomy appear unrelated to their non-enforcement, dormant sodomy statutes do not seem to impose greater constitutional burdens than statutes that are currently enforced.

\section{Sodomy Cases Discussing Cruel and Unusual Punishment}

Several state and federal courts have considered Eighth Amendment challenges to sodomy statutes. These cases uniformly reject the cruel and unusual punishment challenge, although for a variety of reasons. Some older state court opinions rely on the argument that the courts cannot interfere with legislatively determined sentences. That the Helm decision did interfere with a sentence partially invalidates this reasoning. However, the explicit position of the overriding majority of cases, that courts should defer to legislative determinations of difficult punishment issues, particularly in the context of "moral" statutes dealing with crimes such as sodomy, remains valid.

137 See note 68 and accompanying text. 


\section{A. State Court Decisions before Helm and Hardwick}

Before Helm, courts commonly denied Eighth Amendment challenges to sodomy statutes on grounds that any punishment allowed by statute was constitutional. In State $v$ Stubbs, ${ }^{138}$ for example, the North Carolina Supreme Court upheld a prison sentence of seven to ten years for the act of fellatio stating that: "When punishment does not exceed the limits fixed by the statute, it cannot be considered cruel and unusual punishment in a constitutional sense."139 This presumption of constitutionality was the largest single factor used to uphold sodomy statutes prior to Helm..$^{140}$ Although Helm seriously eroded the strength of that presumption, it is important to emphasize that judges historically have deferred to legislative determinations of the proper punishment for sodomy.

The New Mexico Court of Appeals also deferred to the legislature when it upheld an indeterminate sentence (up to life imprisonment) for sodomy. ${ }^{141}$ The court acknowledged the legislature's conclusion that having parole boards determine the length of sentences helped to increase prisoner rehabilitation. "The objects and purposes of the Indeterminate Sentence Act, which form the basis for fixing the maximum penalty of life imprisonment, in our opinion, clearly preclude a determination that cruel and unusual punishment results from the sentence."142

${ }^{238} 266$ NC 295, 145 SE2d 899 (1966).

139 Id at 902.

${ }_{140}$ In Carter $v$ State, 500 SW2d 368, 373 (Ark 1973) the court upheld a twenty-one year maximum sentence and an eight year actual sentence for sodomy between two adult men at a public rest area stating: "No punishment authorized by statute, even though severe, is cruel and unusual unless barbarous or unknown to the law, or so wholly disproportionate to the nature of the offense as to shock the moral sense of the community."

A Missouri court used a similar argument to uphold a thirty year sentence for sodomy committed while the defendant was incarcerated in a county jail. "[F]ixing the limits of punishment is a legislative function, .... and as movant did not receive a sentence greater than the highest limit declared by law, it cannot be held to be excessive . . . or cruel or unusual." Griffith v State, 504 SW2d 324, 330 (Mo App 1974). The court suggested that the appellant should appeal to the legislature because "it is not a proper function for any court to judicially repeal laws on purely sociological considerations-movant would do better to address the cited articles to the General Assembly for it to determine if modern mores require the alteration or expunction of sodomy statutes." Id at 326.

In another 1974 case, the Nebraska Supreme Court upheld a fifteen year sentence for sodomy stating: "Regardless of its severity, a sentence of imprisonment which is within the limits of a valid statute ordinarily is not a cruel and unusual punishment in the constitutional sense." State $v$ Leadinghorse, 192 Neb 485, 222 NW2d 573, 576 (1974).

${ }^{141}$ See Washington v Rodriguez, 82 NM 428, 483 P2d 309 (1971).

142 Id at 311. 
The Maryland Supreme Court in Neville $v$ State ${ }^{143}$ one of the last state cases decided prior to Helm and Hardwick, specifically rejected a proportionality claim explaining that

this Court disclaim[s] any right to oppose the judicial power against the legislative power to define crimes and to fix their punishment, except where the power of the Legislature encounters in its exercise a constitutional prohibition, and in such a case an imperative duty is invoked. In Kelly's case the actual punishment imposed was well below the statutory maximum and affords no basis for relief. ${ }^{144}$

Another Maryland court relied on different grounds to uphold a prison sentence for sodomy: "Imprisonment for years or life has been held not to be cruel and unusual." 145 Although the Helm Court held that life imprisonment without parole was cruel and unusual, the Court has never held imprisonment simply for years to be cruel and unusual. Since all sodomy statutes involve sentences for no more than a term of years, Helm may not alter the tradition of deference to the legislature evident in every prior state sodomy case.

\section{B. The Federal Courts}

Several federal courts have acknowledged the legislature's right to make sodomy unlawful, ${ }^{146}$ but these cases discussed whether sodomy should be illegal at all, rather than whether a specific sentence for sodomy violates the Eighth Amendment. Only one federal case has specifically considered a cruel and unusual punishment challenge to a sodomy statute. In Doe v Commonwealth's Attorney for City of Richmond, ${ }^{147}$ the Virginia District

${ }^{143} 430$ A2d 570 (Md 1981).

144 Id at 581.

${ }^{145}$ Hughes $v$ State, 14 Md App 497, 287 A2d 299, 307 (1972).

${ }^{146}$ In a 1984 case upholding the United States Navy's policy of mandatory discharge for homosexual conduct, the District of Columbia Circuit discussed the legislature's right to legislate on moral issues. "If the revolution in sexual mores that appellant proclaims is in fact ever to arrive, we think it must arrive through the moral choices of the people and their elected representatives, not through the ukase of this court." Dronenburg $v$ Zech, 741 F2d 1388, 1397 (DC Cir 1984).

In Baker $v$ Wade, 774 F2d 1285 (5th Cir 1985), a case upholding a Texas sodomy statute, the Fifth Circuit discussed the proper role of the courts saying: "It is not the role or authority of this federal court to decide the morality of sexual conduct for the people of the state of Texas. . . . Moral issues should be resolved by the people, and the laws pertaining thereto should be written or rescinded by the representatives of the people." Id at 1286-87.

147403 F Supp 1199 (E D Va 1975), affd 425 US 901 (1976). 
Court upheld a statute providing a one to three year sentence for sodomy, relying on the legislature's prerogative to legislate concerning morality. "If a State determines that punishment therefor, even when committed in the home, is appropriate in the promotion of morality and decency, it is not for the courts to say that the State is not free to do so.... In short it is an inquiry addressable only to the State's Legislature."148 The Supreme Court's summary affirmance of this decision is the only specific guidance the Court has given on the application of the Eighth Amendment to sodomy statutes.

Both the state and federal decisions indicate unanimous deference to legislative determinations of punishment. The cases show an understanding by judges that decisions about criminalizing behavior deemed immoral should be made by the people through their elected representatives and not by unelected judges. Although the decision in Helm weakens this argument somewhat, the underlying impetus for courts to defer to legislative and democratic control in the context of sodomy laws remains strong.

\section{After Hardwick}

Since Hardwick, there has been only one significant case that specifically challenged the constitutionality of a sodomy statute based on the Cruel and Unusual Punishment Clause. Perhaps Justice Powell's concurrence in Hardwick encouraged this challenge. In Lambeth $v$ State, ${ }^{149}$ Lambeth received a five year sentence for sodomy. On appeal to the Georgia Supreme Court, he argued that the twenty year maximum penalty for sodomy was cruel and unusual punishment.

The Georgia Supreme Court found that "[w]hile ordinarily the issue of appropriate punishment is left to the legislature, the courts have the power under [the Eighth] amendment to declare unconstitutional those punishments which are overly severe or excessive in proportion to the offense charged."150 The court ultimately emphasized the weight to be given to legislative authority, stating that "legislative discretion must be deferred to unless, under the circumstances, the sentence shocks the conscience."151

The court denied Lambeth relief because he sought to challenge the statutory maximum rather than the five year sentence he

\footnotetext{
148 Id at 1202.

$149257 \mathrm{Ga} 15,354$ SE2d 145 (1987).

150 Id at 145 .

151 Id.
} 
actually received.

[O]nly where the actual sentence imposed upon the defendant is so grossly disproportionate as to shock the conscience will it be set aside as unconstitutional. Since the five-year sentence imposed here, which is well within the statutory twentyyear maximum, does not meet this test under the facts of this case, the defendant has presented no basis for relief. ${ }^{152}$

Although the court gave no indication of how it would have ruled on a maximum twenty year sentence, it would be difficult to argue that a twenty year sentence shocks the conscience while a five year sentence does not.

The Lambeth decision is important because the court initially recognized that the punishment for sodomy must be proportional to the crime. Nevertheless, the court went on to hold that a five year sentence under the specific statute questioned in Hardwick was proportionate to the crime and thus constitutional. ${ }^{163}$

Although the various federal and state cases rely on different analyses, they consistently conclude that sodomy statutes do not impose cruel and unusual punishment. Thus, Powell's assertion in Hardwick that a twenty year sentence for sodomy may violate the Eighth Amendment is not supported by state or lower federal court cases.

\section{Conclusion}

This comment demonstrates that sodomy statutes cannot be challenged successfully on cruel and unusual punishment grounds. While the proportionality doctrine does apply to sodomy statutes, it is extremely difficult to apply and its components can be manipulated to reach any number of results. Moreover, an actual application of the proportionality doctrine shows that it can not invalidate sodomy statutes. Supreme Court precedents do not support Justice Powell's implication in Hardwick that the Georgia sodomy statute may be unconstitutional. Every other court that has considered an Eighth Amendment challenge to a sodomy statute has also rejected it. In addition, the proportionality doctrine offends the notion of democratically elected representatives ascer-

182 Id (emphasis in original).

${ }^{253}$ The comparison between Hardwick and Lambeth is somewhat difficult because Hardwick involved purely consensual homosexual sodomy, while Lambeth was sentenced for consensual sodomy, but was also indicted for rape and aggravated heterosexual oral and anal sodomy. 
taining and codifying the moral views of society and severely limits the power of the states to determine their own unique penalties under our federalist system.

Sodomy statutes are clearly better handled by the legislatures of the individual states. One commentator has noted that "the fact that just over half of the states have eliminated their unenforced sex-related statutes since 1961 shows that it is quite possible to solve the problem through the state legislative process."154 The vast majority of cases in state and lower federal courts and the Supreme Court recognize the inherent advantage of legislative action in this area. "Penologists themselves have been unable to agree whether sentences should be light or heavy, discretionary or determinate. This uncertainty reinforces our conviction that any 'nationwide trend' toward lighter, discretionary sentences must find its source and its sustaining force in the legislatures, not in the federal courts."15s

Judicial determinations of the gravity of sodomy show the inherent weakness of judicial analysis of sentence severity. In analyzing a non-violent crime, such as sodomy, a judge can rely only on her own moral values to determine the appropriate punishment. This is improper because the judge does not represent the views of each individual within her jurisdiction. The legislature, because of the nature of representative government, better reflects the values and beliefs held by various elements of society. Therefore, challenges of state sodomy statutes as cruel and unusual punishment should not be made in the courts. Instead, these challenges should be brought to the legislatures, who are better equipped to make moral judgments and have actually lowered sodomy punishments in several jurisdictions.

${ }^{154}$ Comment, Bowers v. Hardwick: The Uneasy Interaction Between Legislative Intent and Judicial Restraint, 10 Harv J L \& Pub Pol 213, 227 (1987).

${ }^{15 s}$ Rummel, 445 US at 283-84 (footnotes omitted). 